\title{
PENDAMPINGAN ANAK-ANAK JALANAN: KEPEDULIAN DAN KERELAWANAN DARI MAHASISWA
}

\author{
Wahyu Widiantoro \\ Wahyu Relisa Ningrum \\ Arundati Shinta \\ Universitas Proklamasi 45 Yogyakarta \\ Siti Mahmudah \\ Universitas Islam Negeri Maulana Malik Ibrahim Malang
}

\begin{abstract}
Abstrak
Tujuan tulisan ini adalah untuk menjelaskan tentang cara-cara kreatif dalam pemberdayaan anak jalanan. Paradoks di Yogyakarta sebagai kota pelajar adalah semakin banyaknya anak jalanan. Masyarakat kurang peduli dengan keberadaan mereka. Strategi menghadapi mereka adalah memperoleh kepercayaan mereka terlebih dahulu. Langkah selanjutnya adalah menciptakan kegiatan-kegiatan yang menyenangkan seperti belajar di alam bebas. Hal ini karena anak-anak jalanan itu tidak senang dengan suasana yang terkungkung seperti di kelas. Tema belajar dibuat dengan sistem arisan, dan dilakukan sekali setiap minggunya secara rutin. Metode penyampaian materi selalu menggunakan permainan dan game, sehingga tidak membosankan. Metode lainnya yaitu mendongeng, dan adanya buku komunikasi. Buku tersebut berguna untuk mencatat semua kegiatan yang telah dilakukan anak-anak jalanan. Ini adalah cara untuk mengetuk hati orangtua agar lebih peduli pada anak-anak jalanan itu. Kegiatan pendampingan anak-anak jalanan ini menarik karena dilakukan oleh mahasiswa secara suka rela. Mahasiswa telah menjadi relawan dalam bidang pendidikan.
\end{abstract}

Kata kunci: anak jalanan, pendampingan, kepedulian sosial.

Fenomena meningkatnya jumlah anak jalanan di Indonesia, khususnya di Yogyakarta merupakan persoalan sosial yang kompleks. Menjadi anak jalanan memang bukan pilihan yang menyenangkan. Semenjak usia kanak-kanak, mereka sudah harus menghadapi berbagai kekerasan seperti fisik (perkelahian), eksploitasi belas kasihan (mengemis), kejahatan (pencopetan), trafficking (penjualan manusia), seksual (phedophilia, prostitusi), narkoba, bahkan sampai terjadi pembunuhan. Anak jalanan dianggap sebagai bagian anggota masyarakat yang tidak mempunyai masa depan. Keberadaan mereka justru menimbulkan masalah bagi lingkungan sekitarnya. Anak jalanan perlu mendapatkan perhatian yang lebih intensif dan berkesinambungan. Mereka menjadi tanggung jawab masyarakat, karena negara 
tidak mampu menanganinya. Keluarga kecil harapannya untuk mempedulikan mereka, karena keluarga merupakan bagian dari kemiskinan yang juga menjadi penyebab munculnya anak jalanan. Pihak yang diharapkan bisa untuk mengatasi anak jalanan adalah organisasi massa, LSM (Lembaga Swadaya Masyarakat), LPPM di perguruan tinggi, program CSR (Corporate Social Responsibility) dari perusahaan, dan berbagai kelompok relawan masyarakat lainnya.

Persoalan yang berhubungan dengan anak jalanan adalah sulitnya meraih mereka untuk dipertemukan dengan fasilitas vital seperti pendidikan dan kesehatan. Anak jalanan itu memang secara fisik jelas terlihat keberadaannya, namun mereka sering tidak diperhitungkan/tidak dianggap dalam berbagai perencanaan pemerintah. Meraih kepercayaan mereka juga sulit, karena tingginya rasa tidak percayanya terhadap orang-orang yang berusaha mendekatinya. Mereka sudah terlalu sering dieksploitasi. Bila keberadaan mereka tidak segera diatasi maka jumlah mereka semakin lama semakin banyak dan mereka menimbulkan berbagai problem masyarakat.

Tujuan tulisan ini adalah untuk menjelaskan tentang cara-cara kreatif dalam pemberdayaan anak jalanan. Pemberdayaan itu terutama dalam bidang pendidikan yaitu kegiatan belajar bersama-sama. Manfaat tulisan ini adalah untuk memberi inspirasi kepada anggota masyarakat, bahwa selalu ada kemungkinan untuk meraih anak jalanan sepanjang ada kepedulian. Manfaat kedua, memberi inspirsi khsususnya kepada mahasiswa bahwa peduli pada masalah-masalah sosial merupakan ajang penggalian kreativitas. Keunikan tulisan ini adalah pada kepedulian mahasiswa dalam mengadakan kegiatan belajar pada anak-anak jalanan. Hal ini karena sedikit anak muda yang mempunyai kepedulian sosial.

Apa pentingnya tulisan ini? Pembahasan tentang anak jalanan ini penting karena beberapa alasan. Pertama, anak jalanan adalah bagian dari anggota masyarakat. Pengingkaran keberadaan mereka adalah pengingkaran hak azasi manusia. Kedua, anak jalanan itu adalah bagian dari generasi emas Indonesia. Mereka adalah calon pemimpin bangsa. Bila kualitas anak-anak muda mereka terabaikan maka Indonesia akan dipimpin oleh orang-orang yang tidak berkualitas tinggi. Ketiga, bila anak jalanan itu tidak diperhatikan maka mereka akan menjadi generasi yang hilang. Masyarakat akan kehilangan mereka.

\section{Siapa Anak Jalanan itu?}

Anak jalanan adalah anak perempuan / laki-laki berusia di bawah 18 tahun, yang menghabiskan sebagian besar waktunya di jalanan, fasilitas publik, atau tempat yang kosong / terlantar baik untuk hidup maupun bekerja. Mereka tidak 
mendapatkan perlindungan yang memadai. Oleh karena itu anak jalanan rentan menjadi pelaku / korban kejahatan. Julukan sebagai anak jalanan tersebut telah menjadi label atau cap bahwa mereka merugikan masyarakat, bahkan menjadi sumber perilaku kriminal. Hal yang menarik adalah anak-anak tersebut justru senang dengan istilah anak jalanan. Hal ini karena julukan itu telah memberikan mereka semacam identitas sosial dan rasa saling memiliki (UNICEF, 2005).

Anak jalanan itu pada umumnya adalah laki-laki. Jarang ada anak perempuan yang menjadi anak jalanan. Hal ini karena tiga alasan (WHO, 2000). Pertama, anak perempuan yang ditelantarkan keluarganya relatif sedikit. Selain itu anak perempuan dididik untuk patuh, sehingga jarang ada anak perempuan yang nakal. Ketika usianya sudah 13 tahun maka mereka segera dikawinkan sehingga mereka sudah berpindah keluarga. Alasan kedua, penguasa daerah sering mengambil dengan cepat bila ada anak jalanan perempuan. Mereka mungkin saja akan dijual untuk prostitusi atau dipekerjakan sebagai pekerja rumah tangga. Alasan ketiga, anak jalanan perempuan sering menyamar menjadi laki-laki. Tujuannya adalah untuk melindungi dirinya dari kekerasan polisi, pekerja sosial, atau anak jalanan lainnya. Mereka kadang juga hanya keluar malam hari, agar tidak terlihat dengan jelas.

Anak jalanan itu dapat dikategorikan menjadi tiga yaitu a child of the streets, a child on the street, dan a part of a street family (WHO, 2000). Pembagian ini berkaitan dengan keberadaan keluarganya.

- $\quad$ A child of the street adalah anak jalanan yang tidak punya rumah. Keluarganya telah menelantarkannya, atau semua keluarganya sudah tiada. Anak-anak tersebut harus berjuang sendiri agar bisa hidup. Cara mereka hidup adalah berpindah-pindah dari rumah satu teman ke teman lainnya, tinggal di tempat penampungan atau di bangunan-bangunan yang terlantar.

- $\quad$ A child on the street adalah anak jalanan yang masih mempunyai orangtua, dan anak tersebut bertemu orangtuanya secara rutin. Jadi ia pulang setiap malam untuk tidur, namun siang hari ia menghabiskan waktu di jalanan. Hal ini ia jalani karena kemiskinan, rumah terlalu padat, atau adanya kekerasan seksual / fisik di rumah.

- A part of a street family adalah anak dan orangtuanya yang terpaksa tinggal di pojok-pojok jalan. Hal ini terjadi karena kemiskinan, bencana alam, dan perang. Bila mereka berpindah ke pojok jalan yang lain, maka barang-barangnya juga ikut berpindah. Mereka juga mendapat julukan keluarga jalanan. Seringkali, anak-anak jalanan jenis ini bersama-sama saudaranya bekerja di jalanan. 
Berapa jumlah anak-anak jalanan ini? Sangat sulit untuk mendata jumlah anak jalanan. Hal ini karena mereka selalu berpindah-pindah, dan sulit diajak berbicara. Diperkirakan jumlah anak-anak jalanan di seluruh dunia adalah lebih dari 10 juta. Semua negara, baik yang kaya maupun miskin pasti mempunyai anak jalanan (UNICEF, 2005). Di Indonesia, jumlah anak jalanan hanya perkiraan saja, namun jumlahnya semakin lama semakin naik signifikan. Data estimasi dari Departemen Sosial menunjukkan bahwa pada tahun 2002, jumlah anak jalanan adalah 94.674 anak. Pada tahun 2015, angka tersebut diestimasikan menjadi 313.403 anak (Anggiani, 2015). Di Yogyakarta, jumlah anak jalanan juga naik drastis, sampai 100\%. Pada 2002, jumlah anak jalanan adalah 594 anak. Pada 2008, angka itu menjadi 1.200 anak. Mereka terutama berasal dari Kecamatan Tepus Gunung Kidul (Lukman \& Sujarwo, 2012).

Mengapa anak-anak itu menjadi anak jalanan? Anak-anak itu menjadi penghuni jalanan adalah bukan karena kemauannya sendiri, namun semua itu akibat dari kemiskinan. Jadi mereka turun ke jalanan untuk mencukupi kebutuhankebutuhan dasarnya. Berikut adalah alasan-alasan secara lebih detil dibalik alasan kemiskinan yang menjadi latar belakang fenomena anak jalanan (WHO, 2000).

- Untuk mencari uang agar kebutuhannya terpenuhi dan untuk membantu keuangan keluarga. Anak-anak itu tidak bersekolah lagi, mungkin karena putus sekolah dan mereka berada dijalanan tidak mengetahui apa yang akan diperbuatnya. Cara-cara mereka mencari uang antara lain dengan mengemis, membersihkan kendaraan, mengamen, menjual obat bius, prostitusi, penyemir sepatu, dan menjual koran atau barang-barang lainnya. Cara menjajakan produk / jasanya adalah dengan menyelinap diantara kendaraan ketika lampu merah sedang menyala.

- Untuk mendapatkan tempat tinggal. Anak jalanan itu sering berasal dari keluarga yang anggotanya banyak. Padahal ukuran rumahnya kecil, sehingga rumah terasa sesak. Oleh karena itu anak-anak sering memutuskan pergi dari rumah agar adik-adiknya atau anggota keluarga lainnya yang sudah lanjut usia mendapatkan kamar yang lebih longgar. Anak-anak itu juga mungkin berasal dari keluarga-keluarga yang orangtuanya terkena penyakit AIDS / perang / konflik lainnya dan kemudian mati. Anak-anak itu tidak tahu harus pergi kemana untuk sekedar berteduh. Anak-anak itu juga mungkin berasal dari lapas (lembaga permasyarakatan) dan telah dilepas karena hukumannya dianggap selesai. Padahal keluarganya sudah tiada atau menolak menerimanya. Jalanan dengan segala prasarananya adalah penyelamatnya.

\footnotetext{
Seminar Nasional Psikologi "Aktualisasi Potensi Anak Bangsa Menuju Indonesia Emas"
} 
- Untuk melarikan diri dari problem keluarga termasuk penolakan dari keluarga. Banyak anak yang merasa bahwa menjadi anak jalanan adalah cara untuk mengatasi persoalan di rumah. Persoalan itu antara lain konflik dengan orangtua, kekerasan seksual, dan kekerasan fisik (terutama untuk anak-anak yang berkebutuhan khusus). Anak-anak juga sering pergi dari rumah karena orangtua tidak bisa menerima perilaku mereka. Hal-hal itu antara lain karena kehamilan di luar perkawinan, homoseks, dan penyalahgunaan narkoba.

- Untuk melarikan diri dari berbagai tugas rumah yang menjengkelkan. Pada banyak budaya, anak diharapkan untuk membantu orangtua menyelesaikan berbagai tugas rutin rumah tangga. Kadang kala, tugas-tugas itu dianggap terlalu membebani / mengusik kesenangannnya, sehingga mereka merasa seperti budak. Oleh karena itu pergi dari rumah dianggap cara terbaik untuk lepas dari dominasi orang dewasa.

- Untuk melarikan diri dari dari lembaga-lembaga yang terbiasa mengurus anakanak seperti panti asuhan. Anak-anak jalanan itu tidak bisa mematuhi berbagai peraturan di panti asuhan. Mereka justru memandang bahwa panti asuhan adalah seperti penjara. Mungkin para pengelola panti asuhan sudah melakukan tindak kekerasan. Situasi ini terjadi terutama pada anak-anak yang sudah pernah mencicipi bebasnya kehidupan di jalanan, kehidupan yang tidak ada aturannya.

\section{Anak Jalanan dan Mahasiswa}

Bagaimana cara mengatasi permasalahan yang muncul dengan anak jalanan ini? Pemerintah memang sudah mempunyai berbagai program untuk mengatasi anak jalanan. Hal ini karena berdasarkan amanat dari UUD 1945 Pasal 34 ayat 1 bahwa fakir miskin dan anak-anak terlantar dipelihara oleh negara. Pihak yang mendapat amanat tersebut adalah Kementerian Sosial. Kementerian Sosial biasanya akan menyusun program-program penanganan anak jalanan dengan membuat tempat penampungan atau rumah singgah. Dua program andalannya adalah $\mathrm{PKH}$ (Program Keluarga Harapan) dan PKSA (Program Kesejahteraan Sosial Anak) (Tira, 2010). Selain itu Kementerian Sosial juga bisa menggandeng berbagai perusahaan melalu devisi CSR (Corporate Social Responsibility) untuk peduli pada anak-anak jalanan ini. Selanjutnya partai politik pun sering menggunakan anak jalanan untuk keperluan kampanye (Ajikusumo, 2012). LSM (Lembaga Swadaya Masyarakat) tidak ketinggalan, ikut mendampingi anak-anak jalanan dengan berbagai program (Ajikusumo, 2012). 
Keberpihakan negara dan berbagai lembaga itu memang bagus. Hal itu menunjukkan bahwa negara ikut bertanggung jawab. Lembaga-lembaga pun juga peduli. Persoalannya adalah keberpihakan lembaga itu membutuhkan proses panjang. Proses panjang itu antara lain membuat proposal kegiatan, mengurus perijinan, mencari penyandang dana kegiatan, membuat iklan lowongan kerja bagi tenga yang akan menjalankan program, membeli peralatan, membuat kegiatan monitoring dan evaluasi, dan sebagainya. Proses panjang itu pun belum menjamin anak-anak jalanan menjadi aman.

Tulisan ini memberikan alternatif kegiatan pendampingan belajar untuk anakanak jalanan. Hal ini karena anak-anak jalanan itu pada umumnya putus sekolah. Kegiatan itu dilakukan oleh para mahasiswa. Intinya adalah mahasiswa mendampingi kegiatan belajar anak-anak jalanan. Kegiatan ini bisa berjalan lancar karena para mahasiswa tersebut juga memiliki lembaga belajar informal. Mahasiswa tersebut mempunyai kepedulian sosial yang tinggi atau biasa disebut ISR (Individual Social Responsibility) yang tinggi. Kepedulian sosial itu membuat mahasiswa itu merasa dirinya berharga, dan merasa telah menjadi warga negara yang baik (Bénabou \& Tirole, 2010).

Dalam lembaga belajar yang dikelola oleh para mahasiswa yang kepedulian sosialnya tinggi itu, anak-anak sudah terbiasa didampingi dalam proses belajarnya. Anak-anak juga didampingi ketika mengerjakan tugas-tugas sekolah. Peserta les pada bimbingan belajar itu pada umumnya adalah anak-anak yang kurang mampu, sehingga mereka tidak perlu membayar uang les. Bila ada peserta les yang lebih mampu maka mereka diminta untuk membayar uang les. Pembiayaan kegiatan ini adalah subsidi silang (Ningrum, Widiantoro, Mahmudah \& Shinta, 2016).

Kegiatan belajar dengan anak-anak jalanan ini adalah pengembangan lembaga bimbingan belajar tersebut. Tujuan didirikannya lembaga ini adalah lebih kepada tujuan sosial bukan bertujuan untuk mencari keuntungan. Keistimewaan kegiatan ini adalah pendekatannya yang menyenangkan, untuk mencegah kebosanan pada anak-anak jalanan itu. Satu hal yang penting dalam kegiatan ini adalah cara-cara kreatif untuk merebut rasa percaya anak-anak jalanan. Hal ini penting karena anak jalanan itu sering mendapat perlakuan yang tidak menyenangkan dari polisi dan pekerja sosial. Mereka sering dituduh melakukan kejahatan, hanya gara-gara penampilannya kumuh (WHO, 2000). Anak-anak itu sudah terbiasa hidup mandiri, bereaksi cepat, suka menentang, dan selalu curiga (Van Buggenhout, 2015). Oleh karena itu, tawaran untuk belajar bersama-sama secara gratis tentu saja menimbulkan kecurigaan tinggi di antara anak-anak jalanan tersebut. 
Cara kreatif untuk merebut minat anak jalanan itu adalah dengan mengadakan kegiatan belajar di alam bebas. Dalam kegiatan itu anak jalanan diijinkan untuk berperilaku bebas, seperti halnya di jalanan. Hal ini karena anak-anak itu sudah terbiasa hidup bebas, tanpa aturan. Setelah berhasil merebut rasa percaya anak jalanan, langkah selanjutnya adalah mendisain kegiatan belajar yang menarik dan menyenangkan. Langkah ini berdasarkan penelitian Ajikusumo (2012) bahwa program pendidikan luar sekolah yang dilakukan LSM untuk anak-anak yang membutuhkan perlindungan khusus (termasuk anak-anak jalanan), ternyata kurang mampu menarik perhatian anak-anak. Hal ini karena materinya kurang menarik, tidak relevan dengan kebutuhan anak-anak jalanan, dan waktu pemberian materi tidak sesuai dengan mobilitas anak jalan yang tinggi.

Kegiatan belajar yang didisain para mahasiswa ini adalah belajar sambil bermain. Pendekatan dengan permainan penting karena bermain adalah dunia anakanak, dan kegiatan itu memang menyenangkan. Di samping itu, bermain akan merangsang anak dalam hal kreativitas, pengetahuan, perilaku sosial, ekspresi emosi yang sesuai, dan regulasi diri. Bermain juga mengubah tindakan-tindakan anak yang impulsif menjadi perilaku yang penuh perencanaan demi mencapai suatu tujuan. Bermain juga memberi kesempatan pada anak untuk mempraktekkan ketrampilan yang diperlukan ketika dewasa kelak (Berns, 2004). Bermain di alam bebas akan memunculkan rasa ingin tahu anak-anak. Ketika rasa ingin tahu itu muncul, maka itu adalah peluang emas bagi mahasiswa untuk menyampaikan materi pelajaran.

Untuk memelihara semangat belajar anak-anak, maka tema belajar setiap minggunya ditentukan dengan model sistem arisan. Anak-anak diminta untuk mengambil gulungan kertas yang berisi berbagai topik pelajaran. Bila topik pelajaran yang terambil ternyata berlawanan, maka anak diminta untuk bermusyawarah untuk menentukan kesepakatan bersama. Metode arisan ini sebenarnya merupakan cara jitu untuk mengajarkan kerjasama kelompok, pentingnya perilaku saling menenggang, dan juga kepemimpinan. Anak-anak jalanan itu sangat jarang menerima konsep-konsep interaksi sosial yang sehat seperti itu, karena hidup mereka keras dan penuh rasa curiga.

Untuk membunuh rasa bosan belajar, maka metode yang digunakan para mahasiswa adalah game (permainan) psikologi. Metode game ini berhasil menciptakan rasa penasaran anak-anak. Sebagai contoh adalah bermain tebaktebakan dengan kartu yang sudah ditempel dengan angka atau huruf tertentu. Metode game ini juga sesuai untuk anak-anak karena membuat mereka mampu memahami peran, mengembangkan ketrampilan-ketrampilan yang dibutuhkan, 
belajar memahami suatu konsep, dan belajar mematuhi peraturan-peraturan yang sudah disepakati bersama, belajar bekerja sama, dan belajar bersaing dengan sehat (Berns, 2004).

Untuk menanamkan nilai-nilai moral, maka para mahasiswa menggunakan metode cerita / dongeng. Dongeng itu bisa dilakukan sambil membaca buku cerita atau secara lisan. Di samping itu dongeng juga mengajarkan pada anak-anak tentang cara-cara memecahkan suatu permasalahan dan melatih imajinasi. Hal itu dilakukan melalui tokoh cerita yang sedang mengalami kesulitan (Berns, 2004). Setelah selesai mendongeng, menu selanjutnya adalah bermain tebak-tebakan tentang isi cerita. Permainan tebak-tebakan ini melatih daya ingat anak. Tentu saja dalam hal ini pemilihan buku cerita harus diperhatikan. Bila buku cerita itu terlalu vulgar atau berisi kekerasan, perilaku licik demi memenangkan pertarungan, stereotip gender yang sempit, maka buku-buku seperti itu sebaiknya tidak digunakan.

Disain belajar yang menyenangkan bersama anak-anak jalanan ini juga menyertakan metode mengontrol perilaku anak-anak. Metode tersebut dilakukan dengan cara menggunakan buku penghubung antara para mahasiswa (mentor) dengan orangtua anak. Anak-anak jalanan tersebut masih mempunyai orangtua dan hubungan keduanya masih cukup dekat. Biasanya mereka akan bertemu pada malam hari. Anak-anak terpaksa menjadi anak jalanan karena orangtuanya sibuk bekerja sehingga anak-anak tersebut berkeliaran di jalan tanpa ada pengawasan yang memadai. Buku penghubung itu akan berisi tentang segala sesuatu yang dilakukan anak-anak di tempat belajar. Metode buku penghubung ini juga berguna untuk merangsang munculnya perhatian orangtua pada pendidikan anaknya.

\section{KESIMPULAN}

Masalah anak jalanan perlu mendapatkan penanganan dengan segera dan berkesinambungan. Diperlukan kerjasama yang baik antara keluarga, masyarakat dan pemerintah sebagai pemangku kebijakan. Mahasiswa sebagai bagian dari masyarakat, turut ambil bagian dalam pendidikan anak dengan berbagai keunikan pembelajaran yang ditawarkan. Mahasiswa sebagai relawan pendidikan dapat membantu anak jalanan dalam proses pembelajaran. Melalui contoh nyata yang diperlihatkan para mahasiswa (modeling), anak-anak jalanan itu dapat belajar tentang nilai-nilai yang baik dalam kehidupan. Diharapkan anak-anak jalanan itu kelak mendapatkan pandangan yang lebih baik untuk menata masa depannya.

Banyaknya kegiatan altruis dari generasi muda seperti pendampingan pada anak-anak jalanan ini akan menurunkan angka kemiskinan. Tidak hanya anak-anak 
jalanan itu saja yang akan tertolong, tetapi juga orangtua anak-anak tersebut, dan mahasiswa. Berdasarkan informasi dari buku penghubung, maka orangtua dibangkitkan kesadarannya akan pentingnya pendampingan pada anak-anak. Selanjutnya mahasiswa juga akan termotivasi untuk berkreativitas menciptakan materi pelajaran yang menarik. Keberadaan anak jalanan adalah kesempatan bagi mahasiswa untuk menggali potensinya. Kesempatan itu akan melahirkan berbagai ketrampilan berbuat baik. Generasi muda harus melatih ketrampilan berbuat baik ini, karena masa depan bangsa ada di tangannya (Kompas, 2016). 


\section{DAFTAR PUSTAKA}

Ajikusumo, C.R.P. (2012). Faktor-faktor penting dalam merancang progam pendidikan luar sekolah untuk anak jalanan dan pekerja anak. Makara, Sosial Humaniora. 16(1), Juli, 36-48.

Anggiani, D (2015). Pembinaan anak jalanan dan keberadaan rumah singgah: Adakah upaya untuk pembinaan yang menyeluruh? Data Science Indonesia. Retrieved on July 4, 2016 from: http://datascience.or.id/2015/08/02/pembinaan-anak-jalanan-keberadaanrumah-singgah-adakah-upaya-agar-pembinaan-yang-menyeluruh/

Bénabou, R. \& Tirole, J. (2010). Individual and corporate social responsibility. Economica. 77, 1-9. Doi: 10.1111/j.1468-0335.2009.00843.x

Berns, R. M. (2004). Child, family, school, community: Socialization and support. (6th ed). Victoria: Thomson Wadsworth.

Kompas (2016). Pembunuhan dan pemerkosaan: Tersangka berasal dari keluarga harmonis. Kompas. 19 Mei, halaman 27.

Lukman, M. L. \& Sujarwo (2012). Kehidupan anak jalanan di rumah singgah Mandiri Yogyakarta. Diklus. 16 (2), September, 162-172.

Ningrum, W.R., Widiantoro, W., Mahmudah, S., \& Shinta, A. (2016). Guru bimbingan belajar vs orangtua: Potret ketidaksiapan orangtua dalam mendidik anaknya. Prosiding Seminar Nasional \& Call For Paper "Moral Integrity Based on Family". 28 Mei 2016. Malang: Press Unmer, Fakultas Psikologi Universitas Merdeka.

Tira (2010). Workshop anak jalanan. Direktorat Jenderal Rehabilitasi Sosial. Retrieved on July 9, 2016 from: http://rehsos.kemsos.go.id/modules.php?file=article \&name=News\&sid=656 UNICEF. (2005). The state of the world's children 2006. New York: United Nations Children's Fund, UNICEF House, 3 UN Plaza.

Van Buggenhout, M. (2015). Deconsstructing the social concept of street children: The Durban case. Unpublished Thesis. Faculty of Law and Criminology, Criminal Sciences. Vrije Universiteit Brussel.

WHO. (2000). Working with street children: Module 1. A profile of street children. Geneva, Switzerland: World Health Organization, Mental Health Determinants and Populations, Department of Mental Health and Substance Dependence. 